OPEN ACCESS

Edited by:

Linda L. Kusner,

George Washington University,

United States

Reviewed by:

Sarah Jones,

University of Virginia, United States

Katherine Ruzhansky,

Medical University of South Carolina

United States

${ }^{*}$ Correspondence:

Ying Wen

wenying666466@163.com

Specialty section:

This article was submitted to

Autoimmune and

Autoinflammatory Disorders,

a section of the journal

Frontiers in Immunology

Received: 15 August 2020 Accepted: 05 November 2020 Published: 14 December 2020

Citation:

Wang $Y$, Zhao $N$, Yang $J$ and Wen $Y$ (2020) Case Report: Orbital Myositis and

Myasthenia Gravis as Symptoms of

Immune Reconstitution Inflammatory

Syndrome in a Patient With Human Immunodeficiency Virus Infection.

Front. Immunol. 11:595068.

doi: 10.3389/fimmu.2020.595068

\section{Case Report: Orbital Myositis and Myasthenia Gravis as Symptoms of Immune Reconstitution Inflammatory Syndrome in a Patient With Human Immunodeficiency Virus Infection}

\author{
Yanli Wang ${ }^{1}$, Ning Zhao ${ }^{2}$, Jun Yang ${ }^{3}$ and Ying Wen ${ }^{1 *}$
}

\begin{abstract}
1 Infectious Diseases Department, The First Affiliated Hospital of China Medical University, Shenyang, China, 2 Department of Ophthalmology, The First Affiliated Hospital of China Medical University, Shenyang, China, ${ }^{3}$ Neurology Department, The First Affiliated Hospital of China Medical University, Shenyang, China
\end{abstract}

We present a case of a 37-year-old man with HIV infection who had been on antiretroviral therapy for one year. He was admitted to our hospital with red and swollen eyes, acute onset progressive exophthalmos, and intermittent diplopia endured for 7 days. His symptoms, exam, and imaging led to a diagnosis of immune reconstitution inflammatory syndrome associated orbital myositis. His symptoms improved considerably after glucocorticoid therapy. Following a reduction in the oral prednisone dose, he re-presented with left ptosis, which rapidly progressed to bilateral ptosis. Diagnostic testing led to the diagnosis of immune mediated myasthenia gravis. Treatment with pyridostigmine bromide, prednisone, and tacrolimus was initiated. One month later, the patient's symptoms improved significantly. There was a probable association between his symptoms and autoimmune immune reconstitution inflammatory syndrome. This report highlights the importance of recognizing autoimmune disorders in human immunodeficiency virus-infected patients undergoing antiretroviral therapy. Orbital myositis and myasthenia gravis in human immunodeficiency virus-infected patients correlate closely with immunity status following a marked increase in $\mathrm{CD}^{+} \mathrm{T}$ cell counts.

Keywords: orbital myositis, myasthenia gravis, acquired immune deficiency syndrome, autoimmune diseases, antiretroviral therapy

Abbreviations: MG, myasthenia gravis; HIV, human immunodeficiency virus; ART, antiretroviral therapy; GO, Grave's orbitopathy; IRIS, immune reconstitution inflammatory syndrome; ZDV, zidovudine; CT, computed tomography; MRI, magnetic resonance imaging; EMG, electromyography; IgG4-RD, immunoglobulin G4-related disease; AChR, acetylcholine receptor; MuSK, muscle-specific receptor tyrosine kinase; RyR, ryanodine receptor. 


\section{INTRODUCTION}

Antiretroviral therapy (ART)-induced immune reconstitution is characterized by a rapid reduction in viral load and an increase in $\mathrm{CD}^{+} \mathrm{T}$ cell counts. Apart from targeting pathogens, immune reconstitution also targets autoantigens. Immune reconstitution inflammatory syndrome (IRIS)-related autoimmune diseases are uncommon in patients with human immunodeficiency virus (HIV)-infection. This report presents a rare case of a patient with HIV-infection who developed severe orbital myositis as the first IRIS presentation, followed by myasthenia gravis (MG). The sequential occurrence of both conditions in an individual with HIV-infection post-ART has never been reported. Thus, our case emphasizes the importance of recognizing autoimmune disorders as a manifestation of immune reconstitution in patients with HIV-infection undergoing ART.

\section{CASE DESCRIPTION}

A 37-year-old Chinese man presented to our hospital in April 2020 with red, swollen eyes, acute worsening exophthalmos, and intermittent diplopia sustained for 7 days. A year earlier, he had been diagnosed with HIV-1 and had started ART [lamivudine (3TC) $300 \mathrm{mg}$ daily, tenofovir disoproxil $300 \mathrm{mg}$ daily, and dolutegravir $50 \mathrm{mg}$ daily] regimen. Following the ocular symptoms, the tenofovir disoproxil and dolutegravir were replaced with lopinavir/ritonavir $400 \mathrm{mg} / 100 \mathrm{mg}$ twice a day and zidovudine (ZDV) $300 \mathrm{mg}$ twice a day at another hospital one week before this visit. His nadir $\mathrm{CD}^{+}{ }^{+} \mathrm{T}$ cell count was 242 cells $/ \mu \mathrm{l}$, which increased to $717 \mathrm{cells} / \mu \mathrm{l}$ at the time of examination. His HIV RNA load was less than 20 copies $/ \mathrm{ml}$. $\mathrm{He}$ was afebrile. An ophthalmologic examination showed proptosis, congested, and edematous conjunctivae, protruding beyond the lid margin, without ptosis. His corneas, fundi, and visual acuity were normal (Figure 1A), though his eyeball mobility was limited bilaterally. The patient had no personal or family history of autoimmune disease.
Orbital computed tomography (CT) confirmed that both eyes were slightly protruding. The extraocular muscles, especially the superior and inferior recti, were enlarged bilaterally (Figures 2A-C). The optic nerves were normal. Ocular color ultrasound imaging showed mild, bilateral vitreous opacities and widening of the superior ophthalmic veins. Brain magnetic resonance imaging (MRI) showed no parenchymal abnormality. Contrast-enhanced MRI revealed thickening and increased signal intensity of the extraocular muscles, including the tendinous insertions. Both eyelids and lateral soft tissues showed diffuse swelling, without the lacrimal gland and periorbital fat involvement (Figures 2D-F). Aztreonam and clindamycin intravenous antibiotics were administered for 3 days; nonetheless, there was no clinical improvement.

Graves' orbitopathy (GO) was initially suspected. However, thyroid function tests involving measurements of triiodothyronine; thyroxine, thyroid stimulating hormone, thyroglobulin, thyroid peroxidase, and thyrotropin receptor antibodies as well as colorflow Doppler sonography scan, were normal. Further blood results included the following: serum immunoglobins [IgA, $4.03 \mathrm{~g} / \mathrm{L}$ (range 0.7-3.8 g/L), IgG, $12.39 \mathrm{~g} / \mathrm{L}(7-17 \mathrm{~g} / \mathrm{L}), \operatorname{IgM}, 1.89 \mathrm{~g} / \mathrm{L}$ (0.6-2.5 g/L)] and antibody tests (1:100-positive antinuclear antibody and negative antineutrophil cytoplasmic antibody). The orbital involvement in immunoglobulin G4-related disease (IgG4$\mathrm{RD})$ was excluded due to normal serum IgG4 levels, absence of eosinophilia (leukocyte $9.39 \times 10^{9} / \mathrm{L}$, eosinophilia $0.42 \times 10^{9} / \mathrm{L}$ ), and lack of lacrimal gland involvement. Serum antibody tests for herpes simplex virus, varicella-zoster virus, cytomegalovirus, toxoplasma, and syphilis were negative. Serum Epstein-Barr virus-DNA was absent, and the blood T-SPOT. TB assay to detect $\mathrm{T}$ cells primed to mycobacterium tuberculosis (TB) infection was negative. Finally, a diagnosis of IRIS-associated orbital myositis (IRIS-OM) was considered. Dexamethasone ( $5 \mathrm{mg}$ ) was administered intravenously for 5 days, followed by oral prednisone $(30 \mathrm{mg})$ daily. The patient's proptosis, diplopia, and limited ocular movements improved considerably (Figures 1B, C) with an MRI of the extraocular muscles showing reduced swelling (Figures 2G-I).

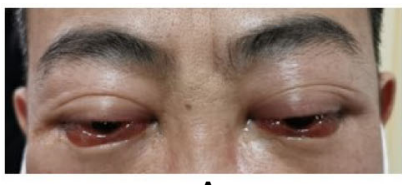

A

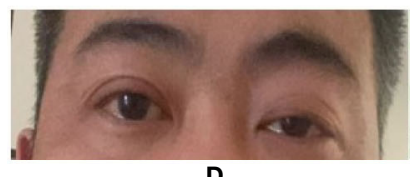

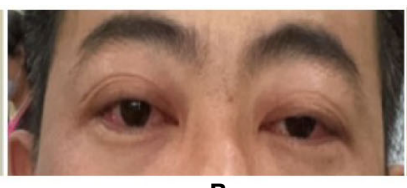

B

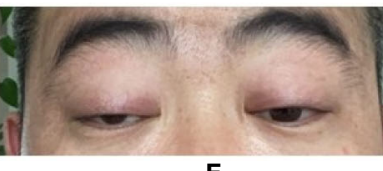

E

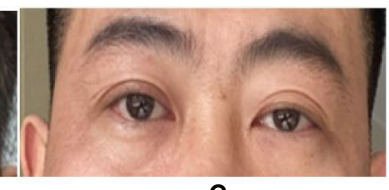

C

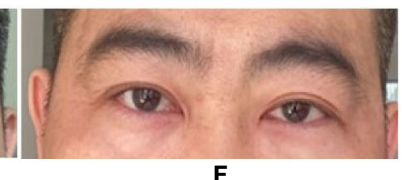

FIGURE 1 | Changes of patient's eyes' appearance. (A) Eyes' appearance before therapy of orbital myositis. (B) After 3 weeks of treatment, the eye signs improved. (C) After 7 weeks of treatment, the eyes' appearance almost got back to normal. (D) New symptoms of left ptosis presented with MG. (E) The patient rapidly progressed to obvious bilateral ptosis when MG was diagnosed. (F) The patient got a great improvement after one month treatment of pyridostigmine bromide, tacrolimus and prednisone. (Informed consent was obtained). 


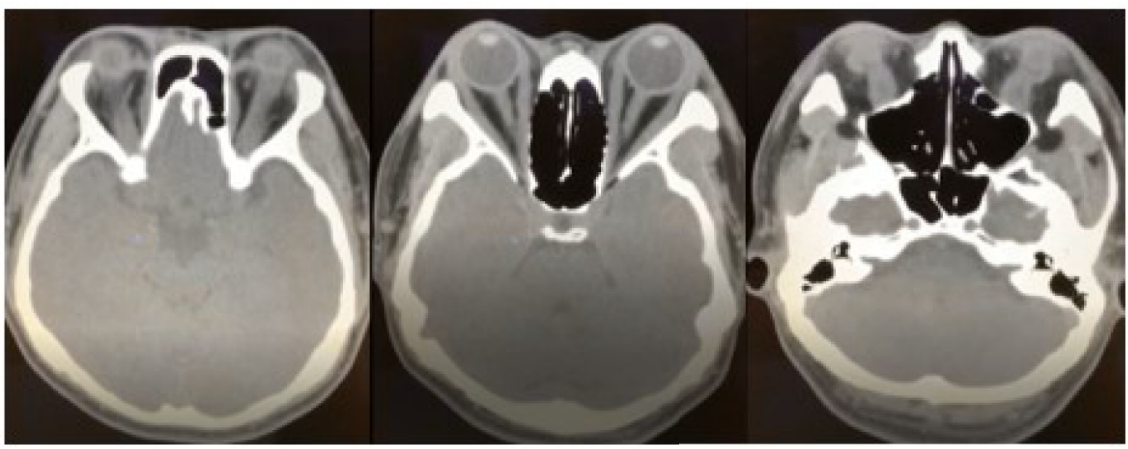

A

B

C

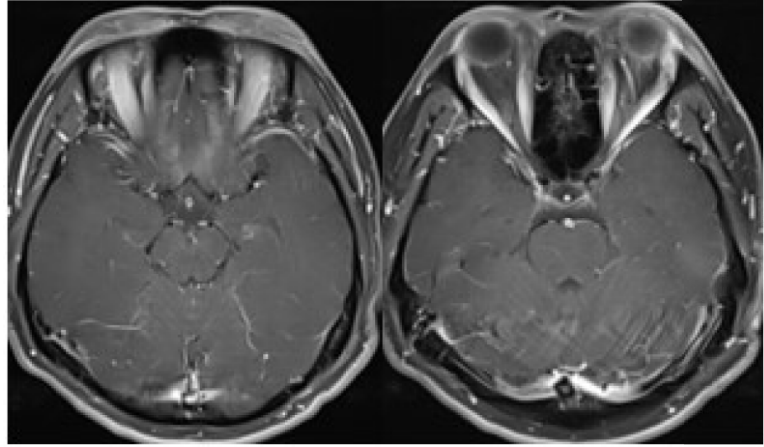

D

E

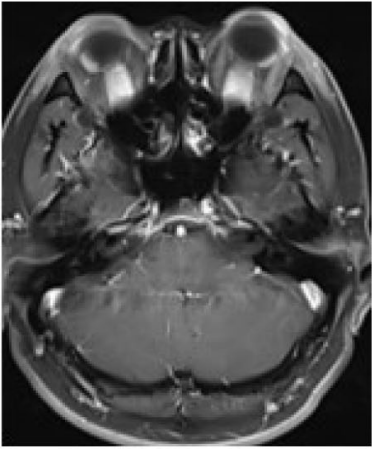

F

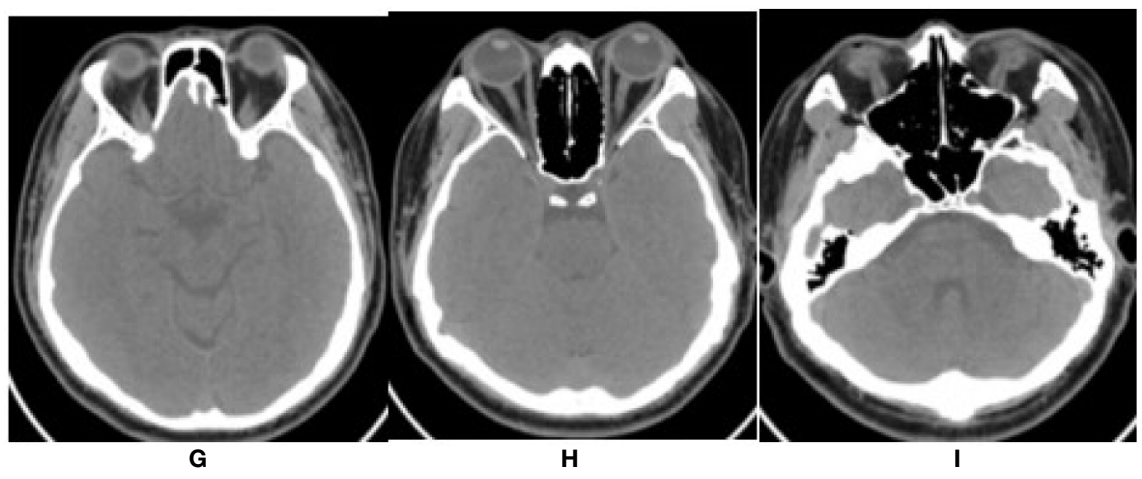

FIGURE 2 | The changes of imaging of extra-ocular muscles. (A-C) Orbital CT scan before therapy showed the bilateral ophthalmic muscles including superior rectus, medial and lateral rectus, inferior rectus were obviously thickened. (D-F) Enhanced MRI revealed thickened and enhanced multiple extra-ocular muscles including tendinous insertion. (G-I) After 3 months of treatment, orbital CT showed bilateral extra-ocular muscles were not thickened.

Three months later, when tapering the prednisone, the patient presented with left ptosis, followed immediately by bilateral ptosis and diplopia (Figures 1D, E). He complained of facial muscles' weakness when chewing and weakness of both upper limbs' muscles while driving. Neurological examination showed bilateral ptosis and disconjugate eye movements without detectable facial or upper limb muscles' weakness. His sensation, coordination, and deep tendon reflexes were normal. A neostigmine challenge test was positive. Further blood tests showed a positive result for the ryanodine receptor (RyR). Acetylcholine receptor (AChR), musclespecific tyrosine kinase (MuSK), and titin receptor antibodies were negative. Creatine kinase levels were within normal limits (105 U/L; normal range 39-308 U/L). A chest CT scan results excluded thymus abnormalities. Routine nerve conduction studies of the right facial nerve, left ulnar nerve, and left median nerve were normal. Low frequency and high frequency repetitive nerve stimulation using the standard approach was used to evaluate the left ulnar nerve and right facial nerve. The left ulnar nerve demonstrated normal responses, whereas the right facial nerve demonstrated 15\% decrement in amplitude at low frequencies without enhancement at high frequencies. Single fiber electromyography (EMG) and needle EMG were not performed. 
TABLE 1 | Table showcasing a timeline with relevant data.

\begin{tabular}{|c|c|c|c|c|c|}
\hline & $\begin{array}{l}\text { Diagnosed with } \\
\text { AIDS }\end{array}$ & $\begin{array}{l}\text { HAART for } \\
7 \text { months }\end{array}$ & $\begin{array}{l}\text { Onset of orbital myositis } \\
\text { (HAART for } 12 \text { months) }\end{array}$ & Onset of MG (HAART for 15 months) & $\begin{array}{l}\text { nowadays (HAART } \\
\text { for } 18 \text { months) }\end{array}$ \\
\hline $\begin{array}{l}\text { CD4 cell } \\
\text { count }(/ \mu l)\end{array}$ & 242 & 299 & 717 & No detection & 369 \\
\hline HIVRNA & No detection & $\begin{array}{l}\text { less than } \\
20 \text { copies/ml }\end{array}$ & less than 20 copies/ml & less than 20 copies $/ \mathrm{ml}$ & less than 20 copies $/ \mathrm{ml}$ \\
\hline $\begin{array}{l}\text { CK (39- } \\
308 \mathrm{U} / \mathrm{L})\end{array}$ & No detection & No detection & No detection & $105 \mathrm{U} / \mathrm{L}$ & $33 \mathrm{U} / L$ \\
\hline symptoms & $\begin{array}{l}\text { Found AIDS in } \\
\text { physical } \\
\text { examination. No } \\
\text { symptoms and } \\
\text { opportunistic } \\
\text { infection }\end{array}$ & $\begin{array}{l}\text { No eyes } \\
\text { symptoms } \\
\text { and muscles } \\
\text { weakness }\end{array}$ & $\begin{array}{l}\text { Swollen of both eyes, acute } \\
\text { worsening exophthalmos and } \\
\text { intermittent diplopia }\end{array}$ & $\begin{array}{l}\text { Bilateral ptosis, chewing weakness and mild both upper } \\
\text { limbs muscles weakness }\end{array}$ & $\begin{array}{l}\text { No eyes symptoms. } \\
\text { No chewing weakness } \\
\text { and upper limbs } \\
\text { muscles weakness }\end{array}$ \\
\hline HAART & 3TC, TDF, DTG & $\begin{array}{l}\text { 3TC, TDF, } \\
\text { DTG }\end{array}$ & $\begin{array}{l}\text { immediately changed to 3TC, } \\
\text { LPV/RTV, ZDV }\end{array}$ & changed to 3TC, LPV/RTV, ZDV for 3 months & 3TC, LPV/RTV, ZDV \\
\hline medication & None & None & $\begin{array}{l}\text { Dexamethasone } 5 \mathrm{mg}, 5 \text { days. } \\
\text { followed by prednisone 30mg } \\
\text { per day and tapering }\end{array}$ & $\begin{array}{l}\text { When prednisone was tapered to } 10 \mathrm{mg} \text {, MG symptom was } \\
\text { developed. pyridostigmine bromide } 60 \mathrm{mg} \text { three times a day, } \\
\text { tacrolimus } 1 \mathrm{mg} \text { twice a day, prednisone } 30 \mathrm{mg} \text { once a day } \\
\text { for two weeks, followed by } 20 \mathrm{mg} \text { once a day for three } \\
\text { months }\end{array}$ & $\begin{array}{l}\text { Pyridostigmine } \\
\text { bromide } 60 \text { mg per } \\
\text { day, prednisone } 20 \\
\text { mg per day tacrolimus } \\
2 \text { mg per day }\end{array}$ \\
\hline
\end{tabular}

Based on the outlined findings, the patient was diagnosed with probable IRIS-associated MG. He was treated with oral pyridostigmine bromide, $60 \mathrm{mg}$ three times per day; tacrolimus, $1 \mathrm{mg}$ twice a day; prednisone, $30 \mathrm{mg}$ once a day for 2 weeks, followed by $20 \mathrm{mg}$ daily for 3 months. One month later, the patient showed considerable improvement (Figure 1F); facial and upper limb muscle weakness improved more rapidly than the ptosis. At the time of this report, the serum creatine kinase was 33 U/L (39$308 \mathrm{U} / \mathrm{L}$ ), the $\mathrm{CD}^{+} \mathrm{T}$ cell count had dropped to 369 cells/ $\mu \mathrm{l}$, and the HIV RNA load was undetectable. He had no complaints with the current pyridostigmine bromide (60 mg daily), prednisone (20 mg daily), and tacrolimus (2 mg daily) treatment regimen, together with ART (Table 1).

\section{DISCUSSION}

We have presented a rare case of a patient with HIV infection who developed severe orbital myositis as the first IRIS presentation, followed by MG. Although in most cases, IRIS appears during the first 3 months after the initiation of ART ('early IRIS'), there could be a later occurrence, generally 3-12 months ('late IRIS') after ART initiation (1). A few cases even occurred as late as 4 years from the initial treatment (2). This patient met the late IRIS criteria, such as presentation of new symptoms and signs at 12 months, achieving an undetectable HIVRNA and obvious increment in CD4 $\mathrm{T}^{+}$cells count after ART especially recent half year. The pathogenesis of early IRIS is probably caused by memory $\mathrm{CD} 4^{+} \mathrm{T}$ cells, while late IRIS could be the result of the second phase of $\mathrm{CD} 4^{+} \mathrm{T}$ cells increase as naive $\mathrm{CD}^{+} \mathrm{T}$ cells migrate from the thymus.

The initial manifestations of the patient were an acute onset of inflammation of the extraocular muscles and proptosis. The reported incidence of proptosis in patients with HIV-infection with ocular diseases is $2.5 \%$ (3). Infections and tumor development are the most common etiologies of orbital involvement in acquired immunodeficiency syndromes of any form (4). GO (5) and IgG4-RD are common inflammatory conditions that affect the orbital tissue. In this case, the clinical manifestations, imaging features, and rapid glucocorticoid response made orbital myositis the most likely diagnosis. Orbital myositis is an autoimmune inflammatory process that primarily involves the extraocular muscles and could be excluded in a diagnosis once neoplasm, primary infection, and systemic disorders, have been ruled out $(6,7)$. Unlike GO, orbital myositis is the term used when the extraocular muscles are the major site of inflammation and constitutes a distinct subset of nonspecific orbital inflammation. Nonspecific orbital myositis is usually unilateral, with the bilateral forms making up $10-20 \%$ of all cases (8). It is characterized by a sudden onset of periocular swelling, pain and redness of the eyelids, proptosis, and ptosis (7). Steroid treatment is effective in one-third of cases $(7,9)$ though spontaneous remission is possible. If steroid therapy fails or recurrence is observed, a biopsy is recommended for further tests (10). Our patient did not undergo a biopsy because of the rapid response to glucocorticoid treatment. Orbital myositis could be the first presenting symptom of HIV infection (11). The orbital soft tissues disease involved in IRIS are rarely reported. Up to now, only two cases were reported in HIV-infected patients. One was a 15-year-old girl with HIV infection undergoing ART for 9 years, who presented orbital myositis with several relapses and remissions (7). Another was reported in a 60-year-old man with HIV infection, who had two orbital inflammation episodes, following $\mathrm{CD}^{+} \mathrm{T}$ cell count improvement with ART (12).

Although GO is the most common reason for inflammation of orbital tissues $(8,13)$, ocular involvement in patients with HIV who have thyroid diseases is uncommon (14). Most patients with GO have abnormal thyroid function tests. Approximately 1-2\% of patients with GO do not have clinically overt thyroid dysfunction, although they almost always display evidence of thyroid autoimmunity, including abnormal levels of 
thyroglobulin thyroid peroxidase and thyrotropin receptor antibodies (8). From their origins to their insertions, the MRI findings of enlarged and edematous ocular muscles could distinguish orbital myositis from GO. Typically, among GO individuals, usually more than one muscle is affected, and the tendinous insertion is not involved (8). Hence, GO could be an IRIS-related unmasking presentation in patients with HIV infection post-ART (15). In IgG4-RD, the most frequent orbital tissue-involved sites are the lacrimal glands and bilateral ocular muscles (7). Although IgG4-related lymphadenopathy has been reported in the initial presentation of HIV infection (16), the orbital disease caused by IgG4-RD has never been reported in patients with HIV infection. The typical manifestations of an orbital lymphoma are diplopia, proptosis, and palpebral ptosis, with a palpable mass in the orbit's anterior region (8). Imaging, ocular fundus examination, and related blood tests could aid in excluding any infectious, vasculitis, and neoplastic processes (7).

MG is an autoimmune disease of neuromuscular transmission, and is primarily mediated by autoantibodies located in the postsynaptic membrane (17). Anti-AChR antibodies bind to the neuromuscular junction, activate complement, and accelerate AChR destruction, leading to failure of neuromuscular transmission and myasthenic symptoms (17). HIV infection itself is responsible for triggering autoimmune diseases through molecular mimicry (18), which improves with progressive immunosuppression (19). Only a few among the several reported cases of patients with HIV infection presented with an unmasking of MG post-ART (Table 2) (19-24), were patients had highly elevated $\mathrm{CD}^{+} \mathrm{T}$ cell counts at the time of $\mathrm{MG}$ onset. Among the seven reported cases (including the present case), four were female and three were males, all aged between 21 and 71 years who presented MG between 12 months and 60 months after ART was started. Immunosuppressive agents were used in most cases, and the short and mid-term prognoses were good. Although patients with HIV infection who also have MG have been reported to have positive anti-AChR or anti-MuSK antibodies (25), the presence of RyR antibodies has not been reported previously. RyR is one of the antigens that activate $\mathrm{Ca}^{2+}$ release channel of the sarcoplasmic reticulum, its RyR antibody is prevalent in thymoma-MG patients who show a good response to tacrolimus (26). Individuals with titin and RyR antibodies might need more active immunosuppressive therapy, while those with RyR antibodies have lower mean daily dosage requirements of pyridostigmine (27). Most RyR antibody-positive patients also have positive AChR antibodies (28). The reported AChR, MuSK, titin, and RyR antibody levels among adult Chinese patients with MG are $82.2,2.3,28.4$, and $23.8 \%$, respectively (28). The existence of RyR antibodies in AChR antibody-negative patients has been reported mainly in East Asian populations but rarely among Caucasians (28). For patients without positive AChR or MuSK antibodies test, confirmation with at least $10 \%$ decrease at the repetitive low frequency stimulation to related nerves is crucial (29). The muscle involvement in individuals with HIV-infection should be differentiated from myopathy, especially ZDV myopathy; long-term ZDV therapy (3-21 months) can cause toxic mitochondrial myopathy (30-32). When orbital myositis

TABLE 2 | Summary of case reports on HIV and MG after ART. M, male; F, female; NM, not mentioned; EFV, Efavirenz; DDI, di-deoxyinosine.

\begin{tabular}{|c|c|c|c|c|c|c|c|c|}
\hline Case & Age & Gender & $\begin{array}{c}\text { Thymic } \\
\text { hyperplasia }\end{array}$ & ART and CD4 cell count ( $/ \mu \mathrm{L})$ & $\begin{array}{l}\text { CD4 cell } \\
\text { count }(/ \mu \mathrm{L})\end{array}$ & Antibody & $\begin{array}{l}\text { ART of MG } \\
\text { onset }\end{array}$ & MG Treatment \\
\hline $\begin{array}{l}\text { Kuntzer T } \\
\text { et al. (19) }\end{array}$ & 21 & $\mathrm{~F}$ & NM & $\begin{array}{l}\text { AZT, 3TC, EFV } 2 \text { years, then AZT was replaced } \\
\text { by TDF for } 8 \text { months, CD4 increased rapidly from } \\
244 \text { to } 575 \text {. }\end{array}$ & $\begin{array}{l}\text { From } 244 \text { to } \\
575 .\end{array}$ & MUSK+ & $\begin{array}{l}\text { TDF, } \\
3 T C \\
\text { EFV }\end{array}$ & $\begin{array}{l}\text { Bromopyrimidine, } \\
\text { prednisone, } \\
\text { thymectomy, } \\
\text { gamma globulin, } \\
\text { plasma exchange, } \\
\text { mycophenolate mofetil, } \\
\text { rituximab. }\end{array}$ \\
\hline $\begin{array}{l}\text { Sherpa et al. } \\
(20)\end{array}$ & 44 & $\mathrm{~F}$ & $\begin{array}{l}\text { No } \\
\text { abnormality }\end{array}$ & $\begin{array}{l}\text { He stopped ART himself. ART was treated again } \\
\text { for } 2 \text { years. CD4 increased from } 53 \text { to } 383 \text {. }\end{array}$ & $\begin{array}{l}\text { From } 53 \text { to } \\
383 .\end{array}$ & MUSK+ & $\begin{array}{l}\text { Emtricitabine, } \\
\text { TDF, RTV }\end{array}$ & $\begin{array}{l}\text { Gamma globulin, } \\
\text { bromopyrimethamine, } \\
\text { azathioprine }\end{array}$ \\
\hline $\begin{array}{l}\text { Ragunathan } \\
\text { et al. (21) }\end{array}$ & 39 & $\mathrm{~F}$ & NM & $\begin{array}{l}\text { Salvage therapy } 12 \text { months, CD4 increased from } \\
100 \text { to } 520 .\end{array}$ & $\begin{array}{l}\text { From } 100 \text { to } \\
520 .\end{array}$ & MUSK+ & $\begin{array}{l}\text { TDF/ } \\
\text { emtricitabine, } \\
\text { Darunavir, } \\
\text { raltegravir }\end{array}$ & $\begin{array}{l}\text { Prednisone, } \\
\text { azathioprine, plasma } \\
\text { exchanges. }\end{array}$ \\
\hline $\begin{array}{l}\text { Knopf and } \\
\text { Menkes (22) }\end{array}$ & 27 & $\mathrm{~F}$ & $\begin{array}{l}\text { thymic } \\
\text { hyperplasia }\end{array}$ & 3 years, CD4 increased from 213 to 432. & $\begin{array}{l}\text { From } 213 \text { to } \\
432 .\end{array}$ & AchR+ & $\begin{array}{l}\text { TDFemtricitabine, } \\
\text { EFV }\end{array}$ & $\begin{array}{l}\text { Bromopyrimethamine, } \\
\text { prednisone, } \\
\text { azathioprine, } \\
\text { thymectomy. }\end{array}$ \\
\hline $\begin{array}{l}\text { Saadat and } \\
\text { Kaminski } \\
\text { (23) }\end{array}$ & 71 & M & NM & $\begin{array}{l}\text { AZT and 3TC were used for } 1 \text { year, combined } \\
\text { with ritonavir for } 3 \text { weeks CD4 is } 290 \text { now (not } \\
\text { mentioned before) }\end{array}$ & $\begin{array}{l}\text { CD4 is } 290 \\
\text { now (NM } \\
\text { before) }\end{array}$ & AchR- & 3TC, DDI & Bromopyrimidine \\
\hline $\begin{array}{l}\text { Kurokawa } \\
\text { et al. (24) }\end{array}$ & 58 & $\mathrm{M}$ & $\begin{array}{l}\text { No } \\
\text { abnormality }\end{array}$ & ART 5 years & NM & MUSK+ & NM & $\begin{array}{l}\text { Bromopyrimethamine, } \\
\text { prednisone, } \\
\text { cyclosporine. }\end{array}$ \\
\hline Our patient & 37 & M & $\begin{array}{l}\text { No } \\
\text { abnormality }\end{array}$ & ART 1 year, CD4 increased from 240 to 717. & $\begin{array}{l}\text { From } 240 \text { to } \\
717 .\end{array}$ & RyR+ & $\begin{array}{l}\text { 3TC, LPV/RTV, } \\
\text { ZDV }\end{array}$ & $\begin{array}{l}\text { Prednisone, } \\
\text { bromopyrimidine, } \\
\text { tacrolimus. }\end{array}$ \\
\hline
\end{tabular}


occurred in this case, the patient's new ART regimen of 3TC, lopinavir/ritonavir, and $\mathrm{ZDV}$ were prescribed to replace the previous regimen of tenofovir disoproxil, 3TC, and dolutegravir. At the onset of MG, the patient had used ZDV for three months. ZDV-induced myopathy was not considered because of the patient's normal serum creatine kinase level a remarkable improvement in the condition without discontinuation of ZDV.

Although MG coexists with a second autoimmune disease in $15 \%$ of cases (33), the sequential appearance of two autoimmune diseases in an individual with HIV infection post-ART is rare. Autoimmunity might result from a disruption in peripheral tolerance in a genetically susceptible host (18). The main clinical implication of this case is that orbital myositis and MG are closely correlated with immune status in patients with HIV-infection when $\mathrm{CD}^{+} \mathrm{T}$ cell counts increase markedly following ART. Attention should be paid to an autoimmune IRIS, which is defined as an exacerbation or the first presentation of autoimmune disease following ART initiation. Notably, the mean interval between the introduction of ART and the onset of autoimmune disease is much longer (several months) than that reported for disorders of infectious origin (a few weeks). Autoimmune IRIS may have a better prognosis than a non-IRIS autoimmune disease. Further study and long-term follow-up are needed to clarify and verify the findings of this case. Since misdiagnosis is common, it is essential to highlight cooperation among multidisciplinary teams, to enable accurate diagnosis and effective treatment.

\section{REFERENCES}

1. Manzardo C, Guardo AC, Letang E, Plana M, Gatell JM, Miro JM. Opportunistic infections and immune reconstitution inflammatory syndrome in HIV-1-infected adults in the combined antiretroviral therapy era: a comprehensive review. Expert Rev Anti Infect Ther (2015) 13:751-67. doi: 10.1586/14787210.2015.1029917

2. French MA, Price P, Stone SF. Immune restoration disease after antiretroviral therapy. AIDS (2004) 18:1615-27. doi: 10.1097/01.aids.0000131375.21070.06

3. Emina MO, Odjimogho SE. Ocular problems in HIV and AIDS patients in Nigeria. Optom Vis Sci (2010) 87:979-84. doi: 10.1097/OPX.0b013 e3181fef198

4. Sodhi PK. Orbital manifestations in patients with acquired immunodeficiency syndrome. Nepal J Ophthalmol (2014) 6:205-19. doi: 10.3126/nepjoph. v6i2.11710

5. Jariyawattanarat V, Sungkanuparph S, Sriphrapradang C. Characteristics Of Graves Disease In Hiv-Infected Patients On Antiretroviral Therapy. Endocr Pract (2020) 26:612-8. doi: 10.4158/EP-2019-0514

6. Hsuan JD, Selva D, McNab AA, Sullivan TJ, Saeed P, O’Donnell BA. Idiopathic sclerosingorbital inflammation. Arch Ophthalmol (2006) 124:1244-50. doi: 10.1001/archopht.124.9.1244

7. Mozzo E, Dona D, Zannin ME, Giaquinto C, Rampon O. Ocular involvement in an HIV-infected patient: not always an infectious disease. An interesting case without apparent cause. Int J STD AIDS (2016) 27:1130-3. doi: 10.1177/ 0956462416629263

8. Marinò M, Ionni I, Lanzolla G, Sframeli A, Latrofa F, Rocchi R, et al. Orbital diseases mimicking graves' orbitopathy: a long-standing challenge in differential diagnosis. J Endocrinol Invest (2020) 43:401-11. doi: 10.1007/ s40618-019-01141-3

9. Yuen SJA, Rubin PAD. Idiopathic orbital inflammation. Arch Ophthalmol (2003) 121:491-9. doi: 10.1001/archopht.121.4.491

10. Li Y, Lip G, Chong V, Yuan J, Ding Z. Idiopathic orbital inflammation syndrome with retro-orbital involvement: a retrospective study of eight patients. PLoS One (2013) 8:e57126. doi: 10.1371/journal.pone.0057126

\section{DATA AVAILABILITY STATEMENT}

The raw data supporting the conclusions of this article will be made available by the authors, without undue reservation.

\section{ETHICS STATEMENT}

Written informed consent was obtained from the individual(s) for the publication of any potentially identifiable images or data included in this article.

\section{AUTHOR CONTRIBUTIONS}

YLW: article writing. NZ, JY, YW: article revising. All authors contributed to the article and approved the submitted version.

\section{FUNDING}

2019 China Medical University Double First Class Construction Infectious Disease AIDS diagnosis and treatment. Fund Number: 3110119068.

11. Fabricius EM, Hoegl I, Pfaeffl W. Ocular Myositis as First Presenting Symptom of Human Immunodeficiency Virus (HIV-1) Infection and Its Response to High-Dose Cortisone Treatment. Br J Ophthalmol (1991) 75:6967. doi: $10.1136 /$ bjo.75.11.696

12. Manta A, Ugradar S, Murta F, Ezra D, Cormack I. Immune Reconstitution Inflammatory Syndrome in a Case of Nonspecific Orbital Inflammation. Ophthalmic Plast Reconstr Surg (2018) 34:e54-6. doi: 10.1097/IOP.0000000000001022

13. Leo M, Menconi F, Rocchi R, Latrofa F, Sisti E, Profilo MA, et al. Role of the underlying thyroid disease on the phenotype of Graves' orbitopathy in a tertiary referral center. Thyroid (2015) 25:347-51. doi: 10.1089/thy.2014.0475

14. Edmunds MR, Mellington F, Ford RL, Torlinska B, Manavi K, Boelaert K. Clinical Challenges of Thyroid Eye Disease in HIV-positive Patients on Highly Active Antiretroviral Therapy. J Clin Endocrinol Metab (2015) 100:379-87. doi: 10.1210/jc.2014-3544

15. Nallu R, Madhavan P, Chirch L, Luthra P. Thyroid Eye Disease Due to Immune Reconstitution Inflammatory Syndrome as a Consequence of Antiretroviral Therapy in the Setting of AIDS. Case Rep Endocrinol (2020) 2020:1728423. doi: 10.1155/2020/1728423

16. Yu HT, Lee CH, Huang SC, Yu SF. Unsuspected human immunodeficiency virus infection presenting asimmunoglobulin G4-related lymphadenopathy: a case report. Int J STD AIDS (2018) 29:92-5. doi: 10.1177/0956462417722479

17. Suthar R, Sankhyan N, Goswami JN, Suri D, Gupta A, Singhi P. Myasthenia Gravis in HIV Positive Girl. Indian J Pediatr (2018) 85:578-9. doi: 10.1007/ s12098-017-2593-9

18. O'Leary JG, Zachary K, Misdraji J, Chung RT. De novo autoimmune hepatitis during immune reconstitution in an HIV-infected patient receiving highly active antiretroviral therapy. Clin Infect Dis (2008) 46:e12-4. doi: 10.1086/524082

19. Kuntzer T, Carota A, Novy J, Cavassini M, Du Pasquier RA. Rituximab is successful in an HIV-positive patient with MuSK myasthenia gravis. Neurology (2011) 76:757-8. doi: 10.1212/WNL.0b013e31820d6290

20. Sherpa M, Metai RK, Kumar V, Hirachan T, Ahmed KU, Atkinson SJ. Comorbid Human Immunodeficiency Virus (HIV) and Muscle-Specific Kinase (MuSK) Myasthenia Gravis: A Case Report and Literature Review. Am J Case Rep (2017) 18:427-30. doi: 10.12659/AJCR.903108 
21. Ragunathan K, Pathak B, Dahal K. MuSK myasthenia gravis as a manifestation of immune restoration disease in an HIV-positive patient. J Neurol (2004) 262:777-8. doi: 10.1007/s00415-015-7639-1

22. Knopf L, Menkes DL. Comorbid HIV and myasthenia gravis: case report and review of the literature. J Clin Neuromuscul Dis (2010) 12:80-4. doi: 10.1097/ CND.0b013e3181fblbe7

23. Saadat K, Kaminski HJ. Ritonavir-associated myasthenia gravis. Muscle Nerve (1998) 21:681-2. doi: 10.1002/(SICI) 1097-4598(199805)21:5<680::AIDMUS26>3.0.CO;2-Y

24. Kurokawa T, Nishiyama T, Yamamoto R, Kishida H, Hakii Y, Kuroiwa Y. Anti-MuSK antibody positive myasthenia gravis with HIV infection successfully treated with cyclosporin: a case report. Rinsho Shinkeigaku (2008) 48:666-9. doi: 10.5692/clinicalneurol.48.666

25. Hung WL, Lin YH, Wang PY, Chang MH. HIV-associated myasthenia gravis and impacts of HAART: one case report and a brief review. Clin Neurol Neurosurg (2011) 113:672-4. doi: 10.1016/j.clineuro.2011.03.019

26. Skeie GO, Aarli JA, Gilhus NE. Titin and ryanodine receptor antibodies in myasthenia gravis. Acta Neurol Scand Suppl (2006) 183:19-23. doi: 10.1111/ j.1600-0404.2006.00608.x

27. Nagappa M, Mahadevan A, Gangadhar Y, Patil S, Bokolia S, Binha PS, et al. Autoantibodies in acquired myasthenia gravis: Clinical phenotype and immunological correlation. Acta Neurol Scand (2019) 139:428-37. doi: 10.1111/ane.13071

28. Hong Y, Li HF, Skeie GO, Romi F, Hao HJ, Zhang X, et al. Autoantibody profile and clinical characteristics in a cohort of Chinese adult myasthenia gravis patients. J Neuroimmunol (2016) 298:51-7. doi: 10.1016/j.jneuroim. 2016.07.001

29. Evoli A, Antonini G, Antozzi C, DiMuzio A, Habetswallner F, Iani C, et al. Italian recommendations for the diagnosis and treatment of myasthenia gravis. Neurol Sci (2019) 40:1111-24. doi: 10.1007/s10072-019-03746-1

30. Sagar A, Mohanty AP, Bahal A. Zidovudine-induced myopathy: A study in Indian patients. J Neurosci Rural Pract (2010) 1:63-6. doi: 10.4103/0976-3147.71717

31. Doughty CT, Amato AA. Toxic Myopathies. Continuum (Minneap Minn) (2019) 25:1712-31. doi: 10.1212/CON.0000000000000806

32. Dalakas MC, Illa I, Pezeshkpour GH, Laukaitis JP, Cohen B, Griffin JL. Mitochondrial myopathy caused by long-term zidovudine therapy. $N$ Engl J Med (1990) 322:1098-105. doi: 10.1056/NEJM199004193221602

33. Gilhus NE, Nacu A, Andersen JB, Owe JF. Myasthenia gravis and risks for comorbidity. Eur J Neurol (2015) 22:17-23. doi: 10.1111/ene.12599

Conflict of Interest: The authors declare that the research was conducted in the absence of any commercial or financial relationships that could be construed as a potential conflict of interest.

Copyright (c) 2020 Wang, Zhao, Yang and Wen. This is an open-access article distributed under the terms of the Creative Commons Attribution License (CC BY). The use, distribution or reproduction in other forums is permitted, provided the original author(s) and the copyright owner(s) are credited and that the original publication in this journal is cited, in accordance with accepted academic practice. No use, distribution or reproduction is permitted which does not comply with these terms. 